\title{
PATTERN OF HIVIAIDS INFECTION IN IRRUA, A RURAL COMMUNITY IN NIGERIA.
}

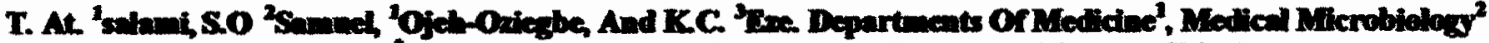 \\ And Radiology", Colloge Or Medicine, Ambrese Ail Universily, Bipoina, Bdo State
}

\section{Correapandence:Email ratsalamiajythoo com}

\begin{abstract}
ABSTrict
This study aims to observe the pattern of HIV infection in Irrua Hospital reoords of patients diagnosed and menaged with HIVIAIDS between Januxy 2001 and December 2004 were retrieved and subjected to statistical analysis. The results show that females have statistically significant lower age; more incidence of double infection with HIV182; and more climical aneamia (low PCV values) compared to their male counterparts.

Women are more likely to be HIV infected then men of similer ages for biological and cultural reasons.

HIV also passes more casily from men to women than vice versa henoe double infection is common.

Ansemia is commoner in females because of incidence of manrow failure due to longer strvival after HIV infection in women. Efiorts should therefore be made to chock the spread of this dreaded infection.

Key words. Fiv. Rurallima Malefiemale.
\end{abstract}

\section{INTRODUCTON}

The seroprevalence of HIV in Nigeria varies acconding to the population groups studied and figures differs from place to place(1) The average mational HIV prevalence rates in Nigeria based on sentinel surveillance study using antenatal records to represent the general population shows a steady increase from $1.8 \%$ in 1990 , to $3.8 \%$ in 1993 , to $4.5 \%$ in 1995 and $5.4 \%$ in 1999 (2) These indicates that approximately 2.6 million Nigerians are HIV positive and may subsequently go on to develop full blown AIDS. Young people are most vulnerable, and in the 1999 study people aged 2024years had the highest rates of infection (3)

The pattern of HV infoction in the rural area and its impect on the commmnity is difierent from that in the uban setting (4) Its epidemiology and clinical manifestation also varies between the male and female sexes (5)
This study aims to see the pattern that exists in this rural anea where our centre is located and the reasons for any such observed tread. This becomes important since the overwhelming majority of people with HIV infection live in the developing worid and these number continues to rise in countries like Nigeria where poverty, poor bealth systems ignorance, nutheadness, and limited resources for prevention and care fuel the spread of the virus.

\section{MTTHODOLOGY}

This is an hospital based study conducted at the Imua Specialist teaching hospital, Imua in Esan central LGA of Edo state, Nigeria.

The hospital records of all patients managed on the medical wands with clinical features of inmmonosuppression and that subsequently tested positive to HIV ELISA antibody between January 2001 and December 2004 were retrieved and information was collected on a previously 
designed questionnaire to case data colloction. Demograhic characteristic of the petients such as age, sex, cocupation were considered. Types of virus imvolved and complications were also considered.

The information obtained was subjected to statistical analysis using Epi-info 6 and a p-value $<0.05$ was taken as significant. A comparison of the features in the males and females was done.

\section{RISULTS}

A total of 134 petients fulfilled the above criteria. There were 68 males and 66 females. The mean age of the patients was 38.53 \pm 5.3 years. The males were found to have a higher mean age of 44.19土9.19years compared to the females with a mean age of $32.87 \pm 3.24$ years ( $P$-value $<0.005$ ). Most of the females were in the twenties while most of the males were in the late thities and forties.

Table 1. Demonstrates the ace distribution of pationts in years.

\begin{tabular}{llll}
\hline Age group(in years) & Males & Females & Total \\
\hline $20-29$ & 0 & $33(50 \%)$ & $33(25 \%)$ \\
$30-39$ & $17(25 \%)$ & $21(32 \%)$ & $38(28 \%)$ \\
$40-49$ & $38(56 \%)$ & 0 & $38(28 \%)$ \\
$50-59$ & $9(13 \%)$ & $8(12 \%)$ & $17(13 \%)$ \\
$60-69$ & $4(6 \%)$ & $4(6 \%)$ & $8(6 \%)$ \\
\hline Total & $68(100 \%)$ & $66(100 \%)$ & $134(100 \%)$
\end{tabular}

Table2. HIV Sintus and the veralence in both caxes. It is worthy of note that HIV2 seropositivity was zero in maies.

\begin{tabular}{llll}
\hline HIV STATUS & MALES & FEMALES & Total \\
\hline HIV1 & $36(53 \%)$ & $8(12 \%)$ & $44(33 \%)$ \\
HIV2 & 0 & $4(6 \%)$ & $4(3 \%)$ \\
HIV1 22 & $32(47 \%)$ & $54(82 \%)$ & $86(64 \%)$ \\
\hline TOTAL & $68(100 \%)$ & $66(100 \%)$ & $134(100 \%)$ \\
\hline
\end{tabular}

The mean packed cell volume(PCV) in both males and females was $26.3 \pm 8.4 \%$ but there was a statistically significant lower value in the females with a mean value of $22.19 \pm 2.12$ compared with that of the males of $30.50 \pm 3.43$.Three of the female patients actually presented with features of amaemic heart failure.
The commonast presenting pethology or illness in both groups was pulmonary Tuberculosis (diagnosed clinically and radiologically).

The Erythrocyte Sedimentation Rate was consistently elevated in both groups especially with co-morbid pulmonary tuberculosis. 


\section{DECUSSION}

There is an equal prevalence of HV infection in both sexes besed on the result of this study in this centre however the age at presentation and the clinical manifestations are different.

The females are considerably younger than their male counterparts with an average age difference of about a decade. This is not totally unexpected since wordtwide, about half of all HV infections are estimated to cocur in young people under 25years(6) In developing countries, $60 \%$ of all HIV infections cocur in 15-24year olds, with a female to male ratio of $2: 1$ in this age group(7) Girls and young women are expecially vulnerable to HIV infection. They marry, or have sexual intercourse with older more sexually experienced men. Older men may approach school giris for sex, since they believe that these girls are still virgins and therefore less likely to be already infected with HIV. Girls are more likely than boys to have been sexually abused at home. This may lead them to run away and eventually to find themselves in commercial sex work. Other girls maybe tempted to leave home by promises of work in another country or region, only to find that the work is actually prostitution. Even those employed legitimately in factories or offices may be targeted for sex by more powerful male bosses.

Globally (8) women have less access to education, have less power to refuse unwanted sex, and to negotiate safer sex, and maybe unaware of having a sexually transmiated disease(STD). In Africa, women aged 15-24years are more likely to be HIV infected than men of similar ages for biological and cultural reasons (9) Other factors include poverty that makes high risk behaviour necessary as a means of survival by selling sex or street hawking of wares which exposes them to sexual abuse or commercial sex; loss or disintegration of their family system (often due to migration or forced displacement) leading to loss of control by panents, schools and the actult community, migration into urben areas where standards of living role models and peer groups are in conflict with traditional norms and values; unavailability of or access to accurate information; and absence of health and social services to help young people due to restrictive policies and legislation.

The result of our study also shows that females have a higher rate of double infection with HIV 1 \& 2 (82\%) to males (47\%). A combination of factors appears to be at work here, including the fact that HIV passes more easily from men to women through sex then from women to men(10); Nicolosi et al found male to female transmission of HIV to be 2.3 times greater than vice versa(11);

Furthermore, male to female transmission is more effective than female to male. Women are slightly more vulnerable physiologically to HIV infection then men. The area of mucous membrane exposed during intercourse is larger in the woman than in the man, and the mucous membrane surface of the vagina (compared to the penis) can more easily be penctrated by virus. Young girls are more vulnerable than women in the 18-45year age group (12)' their immature cervix and relatively low vaginal mucous production present less of a barrier to HIV. A woman who is menstruating is likely to be at higher risk to HIV through sexnal intercourse . Another possible factor for a more effective male to female transmission is the active carriage of HIV in the ejaculate.

Anaemia is a prominemt feature among the females in this study. The PCV value was 
significanty lower in females than in their male counterpants and as stown in the study, three of them actually presented in anaemic heart failure. This is also not totally unoxpected as HIV infection is dominated by peripheral blood cytopacuias (13) Anacmia cocurs in approximately 60-70\% of AIDS patients(14) and it is a common manifestation of HIV disease. The pathophysiology of haematologic complications involves multiple defocts in haemalopoiesis such as decreased numbers of bone marrow progenitors, HIV infection of marrow progenitors with resolting abnormal maturation and proliferation; deficient production of heematopoictic growth factors by the bone manow and HIV induced factor that inbibit normal heamatopoiesis (15). The reason why women scems to be affected more than men is not fully understood. A combination of factors ane clearly involved such as the difference in age patterns of HIV infection in men and women (16) Women tend to become infected far younger than men for both biological and cultural reasons $(9,16)$. The second factor involves survival time from infection to death. The older the patient before HIV infection, the shorter the time between infection and death. Therefore, African women, who as a rule become infected younger than their male connterparts can expect to live longer with HIV on average than men and therefore experience more organ failure such as bone marrow failure leading to ancamia.

The finding of pulmonary tuberculosis(PTB) as the main presenting illness is not surprising as PTB is the most common AIDS defining illness in Africa(17) and this has threatened to overwhelm the tuberculosis control programme in some centres in this country(18) This devastating effect on TB programmes has resulted in over $100 \%$ increase in TB cases in some setting(17-18) which thus creates an increased demmand for diagnostic servious, anti-tuberculous drugs, hospital bets and other supplies and services in areas such as ours where they are alneady in short supply(18)

In conclusion the pattern of HIV infection found in this centre is comparable to that found in other centers in sub-Sahmen Africa and all efforts to check the continued spread of this most dreaded viral infection mast be vigorously pursued.

\section{DEMTRENCES,}

1. Olumide,Y.M, Dada AJ,Sogbama B,ArunaGA. Seroprevalence study of HIV1,HIV2 and HILV1 among patients at the Dermato- Venereology clinic of the Lagos University Teaching Hospital. Int J Dermatiol 1997;36:741-744.

2. Thea Hilhorst, Korrie de Koning and Martin van Here with Florence Abebe, Toyin Jolayemi and Stella Saror. Impact of ADS on rural livelihood in Benue State Nigeria. Implications for policy makers. KMT-Amsterdam with BNARDA and CEC, Makudi, Nigeria. 2003.

3. Centers for Discase Control and Prevention. HIVIAIDS cases reported through Ine 2000. HIVIAIDS Surveillance Report 12, 16-19.

4. UNICEF Publication . The growing impact of HIV infection on women, children, and family life in the developing world. Children and ADSS. An impending calamity 1990;1-24.

5. Focus on AIDS. Nigeria Bulletin of Epidemiology1992; 2:1-24. 
6. UNAIDS. Repont on the Gobal HIV/AIDS Epidemics. Dec1997.

The global HIVIAIDS \& STD Situation and young people in working with young people: A guide to preventing HIVIAIDS 2STDS. Commonwealth Youth Programme1995;12-15.

7. Ainsworth Martha, and Mead Over. The economic impect of AIDS:Shocks, Responses and Outcomes. Technical Working Paper Nol. Africa Technical Department (1992). World Bank, Population, Health and Nutrition Division, Washington DC.

8. Armstrong Jill and Edward Boss. The Dermographic, Economic, and Social Impacts of AIDS. Int J Mann \&Others. AIDS in the world(1992). Cambridge MA; Harvard University press.

9. Fink AJ. A possible explangtion for heterceserual male infection with ADPs. New Eng JMed 1986;315:1167.

10. Nicolosi A,Cornea Leite ML, Musioo MM, Arici C, Gavazzeni $G$ and Lazzarin A. The efficiency of male to female and female to male sexual transmission of HIV. A Study of 730 stable couples. Italian Study on FIV Heterosexual Transmiscion. Epidemiology(1994). 5;570-575.
11. Cameron DW, D'Costa LJ, Maith GM Female to male transmission of HIV1. Risk factor for seroconversion in men. The Lancet1989; Ang 19:404.

12. Zon li, Atin C,Groopman JE. Hrematologic manifestations of the human immune deficiency virus. 1987. Br J Hisematol 66:251-256.

13. Spink $\pi$, Bender BS, Quim TC. Haematologic abnormalities in the acquired immune deficiency syundrome. 1984. Am J Med 77:224-228.

14. Aboulafia D, Mitsuyasu R. Haematologic abnormalities in AIDS. Heamatol Oncol Clin North Am 1992;5:195-214.

15. Fanci AS. The human immunodeficiency virus: Infectivity and mochanisms of pathogenesis. Science 1998; 239:617.

16. World Health Organization. Group at risk. WHO report on the Tuberculosis Epidemics. Geneva: WHO 1996.

17. Ogun SA, Adelowo OO, Familomi OB. Spectrum and cutcome of clinical disease in actults living with AIDS patients in a university teaching hospital- a five year review. Nig Q J Hosp Med 1999;9:177179.

18. WHO/UNAIDS. HIV causing Tuberculosis cases to double in Africa.WHONNAIDS/21. Gencra: WHO,2001. 